\title{
FAKTOR-FAKTOR YANG MEMENGARUHI KEPUTUSAN PEMBELIAN DI INSTAGRAM: PERAN TRUST SEBAGAI VARIABEL MEDIATOR
}

\author{
Abdul Hakim ${ }^{1 *}$, Megawati Simanjuntak², Nur Hasanah ${ }^{1}$ \\ ${ }^{1}$ Sekolah Bisnis, IPB University, Bogor 16128, Indonesia \\ 2Departmen IImu Keluarga dan Konsumen, Fakultas Ekologi Manusia (FEMA), \\ IPB University, Bogor 16680, Indonesia \\ *)E-mail: abdlhkm13@gmail.com
}

\begin{abstract}
Abstrak
Makin banyaknya pelaku bisnis online dan tidak sedikit yang melakukan penipuan mengharuskan konsumen lebih selektif dalam memilih online shop sebelum memutuskan melakukan pembelian. Penelitian ini bertujuan untuk menganalisis pengaruh brand image, perceived risk, e-service quality, dan Electronic Word of Mouth (eWOM) terhadap keputusan pembelian di Instagram melalui trust sebagai variabel mediator. Desain penelitian yang digunakan yaitu cross-sectional study dengan pendekatan kuantitatif. Responden adalah masyarakat Indonesia yang pernah berbelanja di Instagram minimal satu kali selama enam bulan terakhir, berusia di atas 17 tahun dan berdomisili di Jabodetabek dengan jumlah 300 orang yang ditentukan secara voluntary sampling. Data dikumpulkan dengan cara mengisi kuesioner secara daring. Riset membuktikan terdapat pengaruh signifikan dan positif brand image dan eWOM terhadap keputusan pembelian melalui trust. Sebaliknya, tidak ada pengaruh yang signifikan antara perceived risk dan e-service quality terhadap keputusan pembelian melalui trust. Konsumen harus selektif dalam memilih merek, mencari, dan mengumpulkan informasi barang yang akan dibeli. Dalam hal ini, peran Pemerintah pun sangat penting untuk meningkatkan keberdayaan konsumen.
\end{abstract}

Keywords: Instagram, keputusan pembelian, konsumen, online shop, trust

\section{Factors Affecting Purchasing Decision on Instagram: The Role of Trust as Mediator Variable}

\begin{abstract}
Increasingly online businesses and many of them who commit fraud drive consumers to choose an online store and decide to purchase. This study analyzed the effect of brand image, perceived risk, e-service quality, and eWOM on purchasing decisions on Instagram through trust as a mediator variable. The research design used a cross-sectional study and quantitative research methods. The respondents are Indonesian people who have bought on Instagram at least once during the last six months, were over 17 years old, and domiciled in Greater Jakarta, with a total of 300 people determined by voluntary sampling. Data were collected by filling out an online questionnaire. Research proved a significant and positive influence between brand image and eWOM on purchasing decisions through trust. On the other hand, there was no significant effect between perceived risk and e-service quality on purchasing decisions through trust. Therefore, consumers have to be selective when choosing the brand and seek as much information regarding the product that they want to buy. The Government's role is also crucial to increasing consumer empowerment.
\end{abstract}

Keywords: consumer, Instagram, online shop, purchasing decision, trust

\section{PENDAHULUAN}

Pengguna Instagram di Indonesia dalam tiga tahun terakhir mengalami peningkatan yang signifikan. Pada tahun 2018 tercatat pengguna Instagram sebanyak 53 juta orang, kemudian pada tahun 2019 terjadi peningkatan sebesar 17 persen menjadi 62 juta orang dan tahun 2020 menjadi 63 juta orang (We Are Social \& Hootsuite, 2020). Pada sisi lain, e-commerce yang memang dirancang khusus untuk memfasilitasi transaksi antara penjual dan pembeli secara online juga tumbuh dalam beberapa tahun terakhir. Pada tahun 2018 terdapat sebanyak 154,1 juta pengguna $e$ commerce, kemudian pada tahun 2019 sebanyak 168,3 juta dan tahun 2020 tercatat sebanyak 181,5 juta pengguna (Katadata, 2019).

Instagram menjadi salah satu di antara banyak media sosial yang sering digunakan untuk berbelanja online. Sebanyak 80 persen penjual di Indonesia berjualan melalui media sosial, tiga perempat diantaranya berjualan di Instagram (Paypal, 2018). Konsumen tertarik 
berbelanja di Instagram karena lebih mudah di akses, banyak jenisnya, dan terlihat lebih menarik. Konsumen perlu melakukan pecarian informasi, mengingat terdapat keraguan yang dirasakan oleh konsumen; mengingat setidaknya 40,6 konsumen memiliki keraguan dalam berbelanja di Instagram (Dailysocialid, 2016).

Permasalahan yang biasa terjadi antara lain keterlambatan pengiriman dan penerimaan barang, salah kirim barang, cacat pada barang, verifikasi pembayaran barang, keamanan yang rendah, dan minimnya informasi (Dailysocialid, 2016; Kaur \& Quareshi, 2015). Keamanan menjadi fokus utama dalam bertransaksi di Instagram. Sepanjang tahun 2019, sudah tercatat sebanyak 1.617 kasus penipuan online, sebanyak 304 kasus terjadi di Facebook, 413 di Whatsapp dan Instagram sebagai platform dengan kasus penipuan terbanyak mencatat 534 kasus (Ramadhani, 2020).

Permasalahan ini berakibat pada kekecewaan yang konsumen rasakan setelah melakukan pembelian di Instagram. Hasil penelitian sebelumnya menemukan sebanyak empat perenam konsumen kecewa dengan barang yang diterima karena tidak sesuai dengan gambar yang dipajang, harga yang tidak sesuai karena sudah dinaikkan sebelumnya, dan sebanyak dua perenam lainnya kecewa karena ketidakakuratan harga diskon dan rusaknya barang saat diterima (Ibrahim, 2017). Makin banyaknya pelaku bisnis online dan tidak sedikit yang melakukan penipuan mengharuskan konsumen lebih selektif dalam memilih online shop sebelum memutuskan melakukan pembelian. Salah satu tahapan yang dilakukan konsumen adalah memilih dari beberapa alternatif pilihan, sehingga konsumen akan memiliki beberapa alternatif pilihan sebelum akhirnya memutuskan yang terbaik disebut sebagai keputusan pembelian.

Teori yang digunakan dalam penelitian ini adalah perilaku konsumen. Perilaku konsumen berusaha memahami bagaimana konsumen mencari, membeli, menggunakan, mengevaluasi, dan menghabiskan produk dan jasa. Pengambilan keputusan merupakan sebuah proses pemilihan option dari dua atau lebih pilihan alternatif (Sumarwan, 2010). Brand image atau citra merek adalah satu dari beberapa faktor yang diduga dapat memengaruhi keputusan pembelian. Ketika brand image tercipta dengan baik dan positif, ada kemungkinan mampu memengaruhi konsumen untuk memenuhi kebutuhannya dan memberikan kepuasan yang maksimal. Konsumen memilih merek berdasarkan citra yang melekat pada produk. Brand image digambarkan oleh konsumen terkait brand yang dapat diukur dengan refleksi asosiasi merek yang terekam di ingatan konsumen serta sebagai preferensi dan pandangan konsumen terhadap brand tersebut (Keller, 2013).

Faktor lain yang memengaruhi keputusan pembelian adalah perceived risk atau persepsi risiko. Risiko akan selalu terlibat dalam perilaku konsumen, yang berarti apa pun perilaku konsumen selalu terdapat beberapa konsekuensi yang sulit dihindari, sehingga sebagian konsekuensi tersebut kemungkinan tidak akan menyenangkan untuk konsumen. Prinsip saling percaya antara konsumen dan pelaku usaha akan menciptakan sebuah transaksi (Yutadi \& Haris, 2014). Dalam rangka menciptakan penjualan saat ini dan nanti, serta menjaga nilai produk dan perusahaan, ada yang perlu dilaksanakan dan dipertahankan, yaitu e-service quality atau kualitas layanan secara elektronik (Chong \& Man, 2017). Dalam online shop, kualitas pelayanan bisa dimaksudkan sebagai penilaian konsumen secara menyeluruh atas kualitas pelayanan online yang ditawarkan yang tanpa adanya interaksi langsung. $E$ service quality merupakan hal yang penting bagi konsumen karena menjadi opsi yang tepat guna memelihara keterikatan emosional pada konsumen (Shien \& Yazdanifard, 2014).

Electronic Word of Mouth (eWOM) merupakan faktor berikutnya yang dinilai dapat memengaruhi keputusan pembelian. Pada prinsipnya informasi yang diterima konsumen terkait produk mampu memberikan pengaruh dalam transaksi pada masa mendatang (Simanjuntak \& Hamimi, 2019). Faktor lain yang memengaruhi keputusan pembelian adalah trust atau kepercayaan. Trust sangat penting dalam hal hubungan transaksional yang memiliki unsur risiko, contohnya seperti transaksi yang terjadi antara pembeli dengan penjual di internet. Ketika konsumen sudah mendapatkan kepastian dari pihak penjual, trust akan muncul karena adanya komitmen yang diberikan penjual dalam memenuhi semua kewajibannya. Keterkaitan trust dan keyakinan akan memicu transaksi secara online ketika keduanya saling sepakat dengan komitmennya.

Kepercayaan menjadi salah satu faktor esensial bagi online shop di Instagram karena mampu memengaruhi keputusan pembelian. 
Faktor kepercayaan menjadi faktor kunci dalam setiap transaksi secara online. Makin tinggi kepercayaan konsumen, keputusan untuk melakukan pembelian terhadap suatu produk akan meningkat. Sebaliknya, makin rendah kepercayaan konsumen keputusan untuk melakukan pembelian akan menurun (Murwatiningsih \& Apriliani, 2013).

Brand image dapat menciptakan trust atas suatu produk yang kemudian akan mendorong perilaku pembelian terhadap sebuah merek (Rodiques \& Rahanatha, 2018). Penelitian terdahulu tentang pengaruh brand image terhadap trust telah dilakukan. Hasil penelitian menyimpulkan bahwa brand image mampu memengaruhi trust konsumen, hal tersebut berarti makin baik brand image yang dibentuk oleh suatu merek terhadap konsumen maka makin tinggi trust yang dirasakan konsumen terhadap merek tersebut (Wardhana, Putra, \& Wahyudi, 2012). Brand image yang positif juga dapat memengaruhi konsumen untuk melakukan keputusan pembelian. Selain itu, hasil penelitian terdahulu juga telah menemukan adanya pengaruh brand image terhadap keputusan pembelian menunjukkan bahwa makin baik brand image maka akan makin baik pula seseorang dalam mengambil keputusan penggunaan (Rachmawati \& Andjarwati, 2019).

Risiko dapat menjadi kendala bagi niat konsumen untuk melakukan pembelian online. Jika konsumen merasakan tingkat risiko terkait dengan trust pada pembelian produk atau jasa yang terlalu tinggi, konsumen tidak akan menyelesaikan transaksi. Penelitian terdahulu tentang pengaruh perceived risk terhadap trust telah dilakukan. Hasil penelitian menunjukkan bahwa perceived risk mampu memengaruhi online trust dalam minat pembelian di bisnis online (Rosalia \& Ellyawati, 2016). Konsumen memperhatikan risiko yang dihadapi ketika berniat melakukan transaksi secara online sehingga akan berpengaruh pada konsumen secara online, risiko dianggap berdampak pada keputusan konsumen dan perilaku pembelian konsumen (Chen \& Chang, 2012).

Pelayanan yang berkualitas akan membuat pelanggan merasa puas dan percaya bahwa perusahaan telah menyediakan pelayanan yang berkualitas sesuai dengan apa yang diharapkan pelanggan. Hasil penelitian mengungkapkan bahwa kualitas pelayanan yang terdiri dari lima indikator yaitu bukti fisik, kehandalan, ketanggapan, jaminan, dan empati berpengaruh terhadap trust pelanggan (Elrado, Kumadji, \& Yulianto, 2014). Kualitas pelayanan yang diberikan perusahaan juga dapat memengaruhi konsumen dalam membuat suatu keputusan pembelian sebuah produk ataupun jasa (Rozi \& Harti, 2017).

Referensi eWOM yang positif merupakan salah satu upaya untuk membangun trust yang menyebabkan probabilitas yang lebih tinggi dalam proses pembelian. Penelitian terdahulu telah membuktikan bahwa makin positif informasi yang disebarluaskan dari konsumen kepada konsumen lainnya, maka akan meningkatkan trust (Syafaruddin, Suharyono, \& Kumadji, 2016).

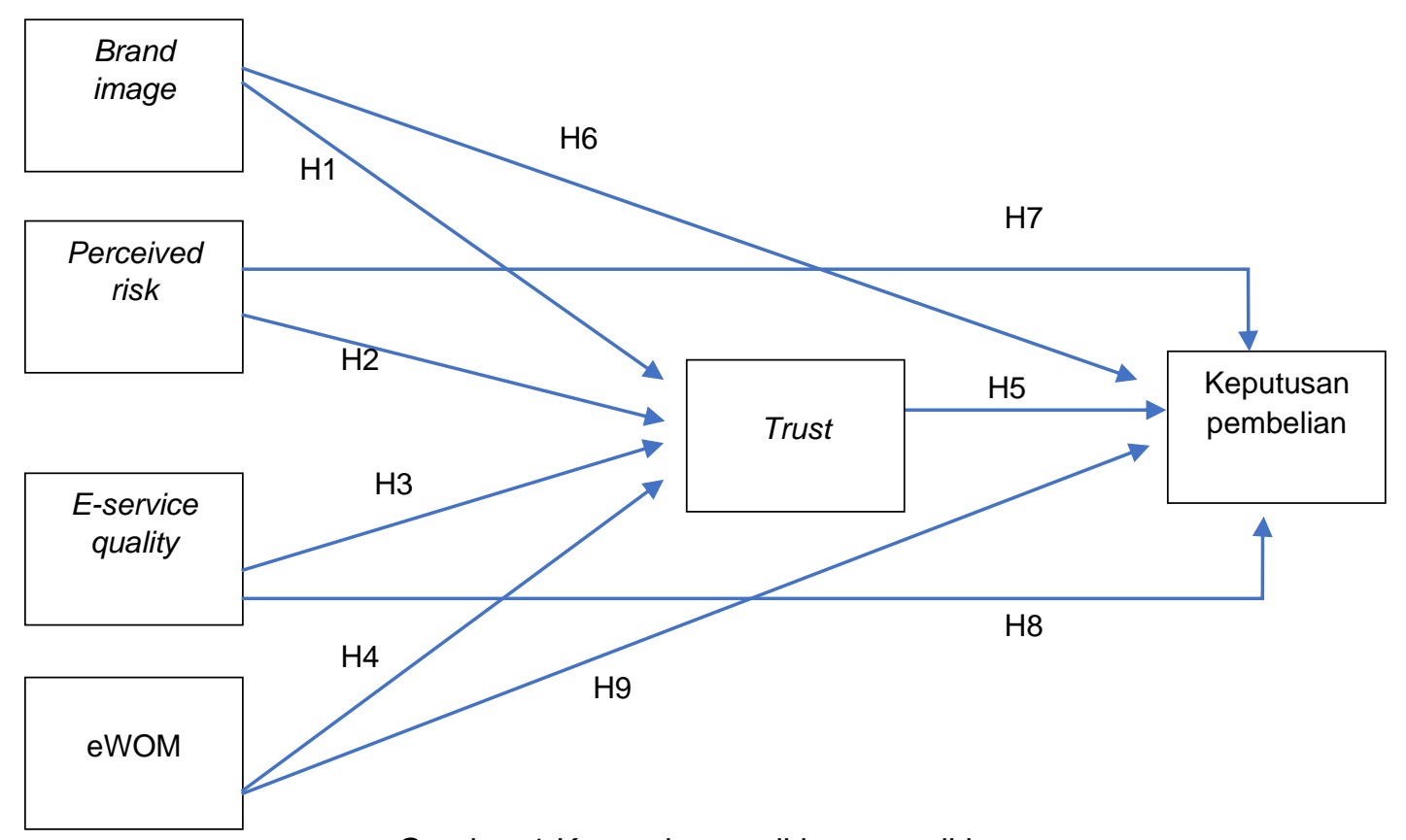

Gambar 1 Kerangka pemikiran penelitian 
Lebih lanjut, media sosial sangat mampu memberikan informasi serta memengaruhi keputusan pembelian. Hal ini disebabkan saat ini pengguna media sosial lebih percaya terhadap opini rekan atau pihak lain daripada strategi pemasaran dari perusahaan dalam memutuskan pembelian. Hasil penelitian menunjukkan bahwa eWOM memiliki andil dalam memengaruhi keputusan pembelian, hal ini menjelaskan bahwa ulasan atau opini dari pembeli lain sangat berpengaruh terhadap sebuah keputusan pembelian seseorang (Priansa, 2016).

Trust muncul ketika konsumen telah mendapatkan kepastian dari pihak lainnya, faktor ini secara kuat memengaruhi keputusan pembelian melalui internet (Sukma, 2012). Penelitian terdahulu tentang pengaruh online trust terhadap keputusan pembelian telah menunjukkan bahwa trust mampu memengaruhi keputusan pembelian, dengan cara konsumen melihat kredibilitas, keandalan penjual, dan kepedulianya terhadap konsumen sehingga konsumen melakukan keputusan pembelian (Nawangsari \& Karmayanti, 2018). Berdasarkan penelitian terdahulu maka penelitian ini bertujuan untuk menganalisis pengaruh brand image, perceived risk, eservice quality, dan eWOM terhadap keputusan pembelian melalui trust.

Berbeda dengan penelitian yang sudah dilakukan sebelumnya yang hanya mengkaji pada produk tertentu, seperti kuliner, fashion, kosmetik, kriya, dan gadget (Dewi, 2018; Tjakraatmadja \& Harjanti, 2018; Restanti, Kusumawati, \& Devita, 2019; Muhammad, Wibowo, \& Lisnawati, 2018; Widiyanti, 2017), penelitian ini tidak mengkhususkan atau menekankan pada produk tertentu. Oleh karenanya, diharapkan mampu mengungkapkan fakta atau temuan terkait dengan perilaku pembelian konsumen di Instagram, khususnya terhadap produk yang paling sering dibeli secara online di Instagram. Sesuai latar belakang dan rumusan masalah yang sudah dipaparkan, maka disusun kerangka pemikiran (Gambar 1) dan hipotesis penelitian.

Hipotesis penelitian yang dijawab dalam penelitian ini adalah:

$\mathrm{H}_{1}$ : Brand image berpengaruh nyata terhadap trust.

$\mathrm{H}_{2}$ : Perceived risk berpengaruh nyata terhadap trust.

$\mathrm{H}_{3}$ : E-Service quality berpengaruh nyata terhadap trust.

$\mathrm{H}_{4}$ : eWOM berpengaruh nyata terhadap trust.
$\mathrm{H}_{5}$ : Trust berpengaruh nyata terhadap keputusan pembelian.

$\mathrm{H}_{6}$ : Brand image berpengaruh nyata terhadap keputusan pembelian.

$\mathrm{H}_{7}$ : Perceived risk berpengaruh nyata terhadap keputusan pembelian.

$\mathrm{H}_{8}$ : E-Service quality berpengaruh nyata terhadap keputusan pembelian.

$\mathrm{H}_{9}$ : eWOM berpengaruh nyata terhadap keputusan pembelian.

\section{METODE}

Penelitian ini menggunakan desain penelitian cross-sectional study dengan pendekatan kuantitatif. Data yang dibutuhkan dalam penelitian ini adalah data primer, yang didapat berdasarkan hasil pernyataan responden dalam pengisian kuesioner. Kuesioner online yang diberikan berisi pertanyaan terstruktur yang dibatasi oleh pertanyaan screening untuk memastikan bahwa kriteria responden sesuai dengan syarat penelitian. Selanjutnya, pertanyaan profiling untuk menggali data demografi responden. Terakhir, kuesioner online berisi pernyataan-pernyataan terkait dengan variabel penelitian yang memengaruhi keputusan pembelian di Instagram. Kuesioner disebar melalui media sosial secara online seperti grup WhatsApp, Instagram, Twitter, dan melalui jejaring pribadi. Penelitian dilakukan di Jabodetabek dengan pengambilan data selama 1 (satu) bulan, mulai dari 27 April 2021 hingga 27 Mei 2021.

Contoh ditentukan menggunakan teknik nonprobability sampling. Teknik voluntary sampling dilakukan untuk mendapatkan responden yang sesuai kriteria dan secara sukarela bersedia mengisi kuesioner untuk memberikan informasi yang dibutuhkan. Kriteria responden adalah pengguna Instagram yang setidaknya pernah membeli suatu produk minimal satu kali dalam waktu sekurang-kurangnya enam bulan terakhir di Instagram dengan usia di atas 17 tahun. Sebanyak 300 orang menjadi responden penelitian ini.

Penelitian ini meliputi tiga variabel, yaitu variabel independen, variabel intervening, dan variabel dependen. Brand image, perceived risk, e-service quality, dan eWOM menjadi variabel independen, kemudian trust menjadi variabel intervening, dan keputusan pembelian menjadi variabel dependen. Brand image merupakan representasi konsumen terhadap suatu merek yang terbentuk dari informasi dan pengalaman masa lalu. Variabel brand image terdiri atas tiga dimensi, yaitu product image, 
corporate image, dan user image dengan masing-masing dimensi memiliki dua indikator.

Selanjutnya, perceived risk adalah persepsi yang diyakini konsumen akan menimpa dirinya saat bertransaksi secara online di Instagram. Variabel perceived risk terdiri atas enam dimensi, yaitu financial risk, product performance risk, social risk, psychological risk dan delivery risk, dengan masing-masing dimensi memiliki dua indikator, kecuali dimensi delivery risk memiliki satu indikator (Hong, 2015).

E-service quality merujuk pada pelayanan optimal yang diharapkan konsumen dari sebuah online shop saat berbelanja di Instagram. Variabel e-service quality terdiri atas empat dimensi, yaitu efficiency, privacy, site aesthetic, dan responsiveness dengan masing-masing dimensi memiliki dua indikator (Zavareh et al., 2012).

eWOM merupakan pernyataan dari konsumen terdahulu, baik itu yang bersifat positif maupun negatif terhadap suatu produk yang sudah dikonsumsinya dan akan digunakan kembali oleh calon konsumen baru sebagai pertimbangan sebelum membeli produk tersebut. Variabel eWOM terdiri atas tiga dimensi, yaitu content, intensity, dan valence of opinion (Goyette et al., 2010). Pada dimensi intensity dan content terdapat tiga indikator dan dimensi valance of opinion memiliki dua indikator.

Trust merupakan rasa percaya yang hadir antara dua pihak terkait perilaku dan maksud (Yuliati, Dradjat, \& Simanjuntak, 2020) atau kepercayaan konsumen yang timbul karena konsumen merasa puas dan nyaman atas pemenuhan tanggung jawab penjual sebelum, saat, dan sesudah transaksi dilakukan. Variabel trust terdiri atas tiga dimensi, yaitu competence, benevolence, dan integrity dengan dua indikator pada masing-masing dimensi.

Keputusan pembelian adalah pilihan akhir konsumen dari beberapa alternatif pilihan yang ada. Variabel keputusan pembelian terdiri atas lima dimensi, yaitu pengenalan kebutuhan, pencarian informasi, pengevaluasian alternatif, penentuan pilihan, dan pasca pembelian (Kotler \& Amstrong, 2014). Setiap dimensi memiliki dua indikator.

Seluruh variabel pada penelitian ini diukur menggunakan skala interval lima tingkatan untuk menyatakan jawaban responden dari tiap indikator. Variabel brand image, perceived risk, e-service quality, dan trust menggunakan skala 1) STS = sangat tidak setuju; 2) TS = tidak setuju; 3) CS = cukup setuju; 4) $S=$ setuju; dan 5) SS = sangat setuju. eWOM dan keputusan pembelian menggunakan skala 1) $\mathrm{TP}=$ tidak pernah; 2) $\mathrm{JR}=$ jarang; 3) $\mathrm{KD}=$ kadang-kadang; 4) SR = sering; dan 5) $\mathrm{SL}=$ selalu. Proses pengolahan data dilaksanakan pasca terkumpulnya data dengan bantuan aplikasi Microsoft Excel, selanjutnya dilakukan analisis Structural Equation Modelling (SEM) dengan aplikasi SmartPLS. Analisis deskriptif dimanfaatkan untuk mendapat gambaran terkait karakteristik demografi dan perilaku pembelian responden. Analisis SEM dilakukan untuk menganalisis pengaruh brand image, perceived risk, e-service quality, dan eWOM terhadap keputusan pembelian melalui trust.

\section{HASIL}

\section{Karakteristik Demografi Responden}

Jenis kelamin pria mendominasi demografi responden penelitian ini yakni sebanyak 193 responden atau 64,3 persen dari total contoh. Selain itu, lebih dari setengah konsumen Instagram yang menjadi responden penelitian ini didominasi oleh usia 26 hingga 33 tahun yakni 180 responden (60\%). Pendidikan terakhir para responden didominasi sarjana sebanyak 145 responden (48,33\%). Berdasarkan karakteristik pekerjaan, mahasiswa mendominasi sebanyak 99 responden (33\%). Pendapatan responden terbanyak berada pada rentang Rp. 2,5 juta hingga Rp. 5 juta yaitu sejumlah 53,33 persen dengan pengeluaran terbanyak kurang dari Rp. 1 juta per bulan (49,67\%). Hasil penelitian menunjukkan bahwa sebesar 26 persen responden berdomisili di DKI Jakarta (Tabel 1).

\section{Perilaku Pembelian}

Berdasarkan analisis deskriptif didapatkan informasi bahwa produk yang paling sering dibeli responden didominasi oleh produk fashion sebesar 46 persen. Pada setiap pembelian suatu produk, mayoritas responden membeli dengan jumlah pembelian paling sering sebanyak dua buah, yaitu sebesar 51,67 persen. Frekuensi pembelian sebuah produk yang paling sering dilakukan sebanyak dua kali yaitu sebesar 34 persen. 
Tabel 1 Persentase sebaran responden berdasarkan karakteristik sosial ekonomi

\begin{tabular}{|c|c|c|c|}
\hline Karakteristik & Kategori & $\mathrm{n}$ & $\%$ \\
\hline \multirow[t]{2}{*}{ Jenis kelamin } & Pria & 193 & 64,33 \\
\hline & Wanita & 107 & 35,67 \\
\hline \multirow[t]{3}{*}{ Usia } & $18-25$ & 112 & 37,33 \\
\hline & $26-33$ & 180 & 60,00 \\
\hline & $34-41$ & 8 & 2,67 \\
\hline \multirow[t]{4}{*}{ Pendidikan } & SMA/SMK & 103 & 34,33 \\
\hline & Diploma & 51 & 17,00 \\
\hline & Sarjana & 145 & 48,33 \\
\hline & Pascasarjana & 1 & 0,33 \\
\hline \multirow[t]{6}{*}{ Pekerjaan } & Mahasiswa & 99 & 33,00 \\
\hline & $\begin{array}{l}\text { Ibu Rumah } \\
\text { Tangga }\end{array}$ & 30 & 10,00 \\
\hline & ASN/TNI/Polri & 35 & 11,67 \\
\hline & $\begin{array}{l}\text { Pegawai } \\
\text { Swasta }\end{array}$ & 90 & 30,00 \\
\hline & Profesional & 14 & 4,67 \\
\hline & Wirausaha & 32 & 10,67 \\
\hline \multirow{6}{*}{$\begin{array}{l}\text { Pemasukan per } \\
\text { bulan }\end{array}$} & $<$ Rp. 1 juta & 6 & 2,00 \\
\hline & $\begin{array}{l}\text { Rp. } 1 \text { juta - } \\
\text { Rp. } 2,5 \text { juta }\end{array}$ & 67 & 22,33 \\
\hline & $\begin{array}{l}\text { > Rp. } 2,5 \text { juta } \\
\text { - Rp. } 5 \text { juta }\end{array}$ & 160 & 53,33 \\
\hline & $\begin{array}{l}>\text { Rp. } 5 \text { juta - } \\
\text { Rp. } 7,5 \text { juta }\end{array}$ & 61 & 20,33 \\
\hline & $\begin{array}{l}\text { > Rp. } 7,5- \\
\text { Rp. } 10 \text { juta }\end{array}$ & 4 & 1,33 \\
\hline & > Rp. 10 juta & 2 & 0,67 \\
\hline \multirow{6}{*}{$\begin{array}{l}\text { Pengeluaran } \\
\text { untuk belanja } \\
\text { online per bulan }\end{array}$} & $<$ Rp. 1 juta & 149 & 49,67 \\
\hline & $\begin{array}{l}\text { Rp. } 1 \text { juta }- \\
\text { Rp. } 1,5 \text { juta }\end{array}$ & 121 & 40,33 \\
\hline & $\begin{array}{l}>\text { Rp. } 1,5 \text { juta } \\
- \text { Rp. } 2 \text { juta }\end{array}$ & 14 & 4,67 \\
\hline & $\begin{array}{l}>\text { Rp. } 2 \text { juta - } \\
\text { Rp. } 2,5 \text { juta }\end{array}$ & 7 & 2,33 \\
\hline & $\begin{array}{l}\text { > Rp. } 2,5 \text { juta } \\
\text { - Rp. } 3 \text { juta }\end{array}$ & 5 & 1,67 \\
\hline & $>$ Rp. 3 juta & 4 & 1,33 \\
\hline \multirow[t]{5}{*}{ Domisili } & Jakarta & 78 & 26,00 \\
\hline & Bogor & 60 & 20,00 \\
\hline & Depok & 54 & 18,00 \\
\hline & Tangerang & 59 & 19,67 \\
\hline & Bekasi & 49 & 16,33 \\
\hline
\end{tabular}

Keterangan: $\mathrm{N}=$ jumlah responden; \%=persentase

Hasil penelitian menunjukkan bahwa selain melakukan pembelian secara online di Instagram, responden juga melakukan pembelian di e-commerce sebesar 53,69 persen. Penelitian ini juga menunjukkan bahwa yang paling mudah digunakan untuk melakukan pembelian secara online adalah
Instagram (69,67\%). Selanjutnya, platform yang paling dipercaya dalam melakukan pembelian secara online adalah Instagram dan e-commerce dengan persentase yang sama sebesar 49,33 persen. Terkait dengan pelayanannya, responden menilai bahwa Instagram memiliki pelayanan yang paling baik sebesar 58 persen. Selain dilihat dari sisi positif, pembelian secara online juga memiliki sisi negatif. Sebanyak 10,33 responden persen pernah mengalami kekecewaan/pengalaman buruk dalam berbelanja online. Platform Facebook menempati urutan kesatu sebagai platform yang mengecewakan sebesar 48,38 persen.

\section{Hasil Uji Outer Model (Model Pengukuran)}

Model pengukuran atau outer model dengan indikator reflektif dievaluasi dengan validitas konvergen dan validitas diskriminan dari indikatornya. Untuk uji validitas dari konstruk dengan indikator reflektif dapat dilihat dari korelasi antara skor indikator dengan skor konstruknya. Indikator individu dianggap valid jika memiliki nilai korelasi di atas 0,5. Berdasarkan hasil analisis, sebanyak 47 indikator variabel construct memiliki nilai factor loading di atas 0,5. Hal ini menunjukkan indikator tersebut valid sebagai pengukur construct dan telah merefleksikan variabel laten. Secara keseluruhan, nilai AVE dari masing-masing indikator yang mengukur semua variabel di atas 0,5. Hal ini menunjukkan indikator memiliki validitas yang cukup baik.

Selanjutnya, dilakukan uji reliabilitas dengan instrumen Cronbach's alpha dan composite reliability. Suatu indikator dikatakan reliabel apabila nilai dari Cronbach's alpha lebih dan composite reliability di atas 0,7 . Perolehan nilai uji reliabilitas menunjukkan bahwa variabel laten yang digunakan dalam penelitian ini memiliki nilai lebih dari 0,7 sehingga reliabilitas dari variabel laten yang digunakan dalam penelitian ini telah terpenuhi.

\section{Hasil Uji Inner Model (Model Struktural)}

Setelah lolos uji validitas dan reliabilitas, selanjutnya dilakukan evaluasi inner model. Parameter yang digunakan untuk evaluasi inner model dalam SmartPLS adalah koefisien determinan $\left(U j i R^{2}\right)$ dan koefisien jalur atau $t$ value. Nilai $\mathrm{R}^{2}$ digunakan untuk mengukur tingkat variasi perubahan variabel independen terhadap variabel dependen. Nilai $\mathrm{R}^{2}$ pada variabel trust sebesar 0,843 dan nilai variabel keputusan pembelian sebesar 0,913. 


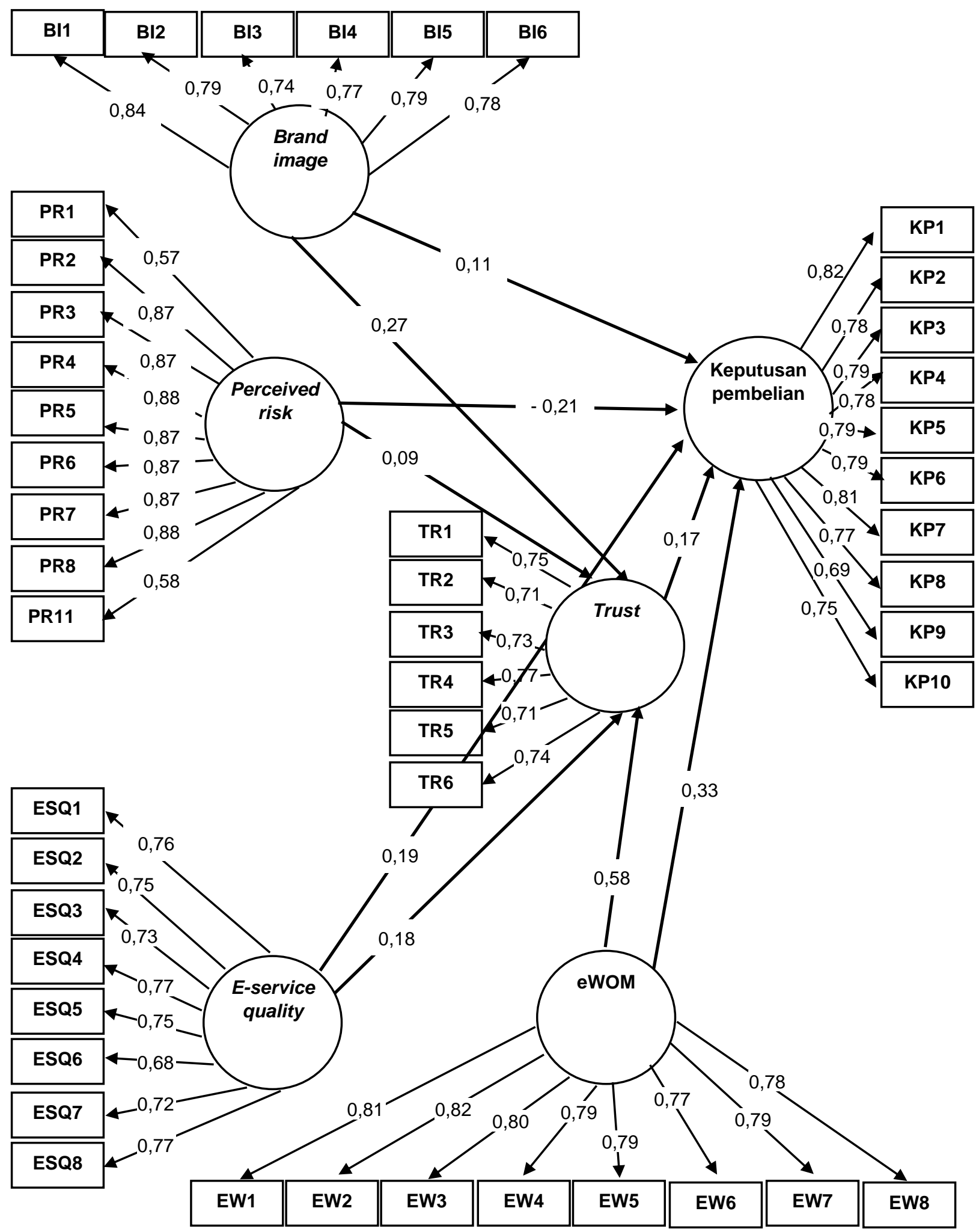

Keterangan:

$\mathrm{PR}=$ Perceived Risk

$E S Q=$ Electronic Service Quality

eWOM = Electronic Word of Mouth

$\mathrm{TR}=$ Trust

$\mathrm{KP}=$ Keputusan Pembelian

$\mathrm{BI}=$ Brand Image 
Tabel 2 Hasil koefisien jalur dan uji t pengaruh langsung antar variabel laten

\begin{tabular}{lrrll}
\hline \multicolumn{1}{c}{ Jalur } & Koefisien Jalur & t-hitung & Kesimpulan & Keterangan \\
\hline Brand image $>$ trust & 0,271 & 4,180 & Signifikan & H1 diterima \\
Perceived risk $\rightarrow$ trust & 0,097 & 1,755 & Tidak signifikan & H2 ditolak \\
E-service quality $\rightarrow$ trust & 0,182 & 2,106 & Signifikan & H3 diterima \\
eWOM $->$ trust & 0,581 & 6,894 & Signifikan & H4 diterima \\
Trust $->$ keputusan pembelian & 0,173 & 2,744 & Signifikan & H5 diterima \\
Brand image $->$ keputusan pembelian & 0,112 & 2,102 & Signifikan & H6 diterima \\
Perceived risk $->$ keputusan pembelian & $-0,210$ & 4,616 & Signifikan & H7 diterima \\
E-service quality $->$ keputusan pembelian & 0,188 & 3,257 & Signifikan & H8 diterima \\
eWOM $->$ keputusan pembelian & 0,334 & 4,207 & Signifikan & H9 diterima \\
\hline
\end{tabular}

Nilai koefisien determinasi $\left(\mathrm{R}^{2}\right)$ digunakan untuk menghitung Goodness of Fit (GOF) atau (uji kelayakan model) karena dalam SmartPLS tidak tersedia menu khusus untuk menghitung GOF. Nilai GOF digunakan untuk menunjukkan dan menggambarkan kecocokan suatu model. GOF mencerminkan seberapa besar variabel dependen $(Y)$ dapat diterangkan oleh variabel independen $(X)$.

Berdasarkan hasil perhitungan, dihasilkan nilai $\mathrm{Q}^{2}$ sebesar 0,986 . Hal tersebut diartikan bahwa variabel independen $(\mathrm{X})$ yang terdiri atas brand image, perceived risk, E-Service Quality, eWOM (electronic word of mouth), dan trust dapat menjelaskan sebesar 98,6 persen keputusan pembelian dan sisanya 11,4 persen dijelaskan oleh variabel lain yang tidak masuk di dalam model. Dengan demikian, dapat disimpulkan bahwa model penelitian ini adalah baik untuk dijadikan suatu model penelitian karena nilai $\mathrm{Q}^{2}$ lebih dari 80 persen. Hal ini dikarenakan makin tinggi nilai $\mathrm{Q}^{2}$ maka makin baik model prediksi dari model penelitian yang diajukan.

\section{Pengujian Hipotesis}

Tabel 3 Hasil koefisien jalur dan uji T pengaruh tidak langsung antara variabel laten

\begin{tabular}{lccl}
\hline \multicolumn{1}{c}{ Jalur } & $\begin{array}{c}\text { Koefisien } \\
\text { jalur }\end{array}$ & $\begin{array}{c}\mathrm{t}- \\
\text { hitung }\end{array}$ & Kesimpulan \\
\hline $\begin{array}{l}\text { Brand image - } \\
\text { trust }->\end{array}$ & 0,047 & 2,299 & Signifikan \\
$\begin{array}{l}\text { keputusan } \\
\text { pembelian } \\
\text { Perceived risk }\end{array}$ & & & \\
$->$ trust $->$ & 0,017 & 1,541 & $\begin{array}{l}\text { Tidak } \\
\text { signifikan }\end{array}$ \\
$\begin{array}{l}\text { keputusan } \\
\text { pembelian } \\
\text {-service }\end{array}$ & & & \\
$\begin{array}{l}\text { quality }->\text { trust } \\
->\text { keputusan } \\
\text { pembelian } \\
\text { eWOM }->\end{array}$ & 0,031 & 1,532 & $\begin{array}{l}\text { Tidak } \\
\text { signifikan } \\
\text { trust }->\end{array}$ \\
$\begin{array}{l}\text { keputusan } \\
\text { pembelian }\end{array}$ & 0,100 & 2,686 & Signifikan \\
\hline
\end{tabular}

Setelah melakukan perhitungan Goodness of Fit (GOF), analisi selanjutnya adalah pengujian hipotesis dengan koefisien jalur. Koefisien jalur adalah koefisien yang menunjukkan tingkat signifikasi dalam pengujian hipotesis. Hipotesis yang digunakan dalam penelitian ini adalah hipotesis satu sisi (one-tailed). Hipotesis diterima apabila memiliki nilai t-statistik lebih dari 1,96. Gambar model struktural hasil bootstrapping ditunjukkan pada Gambar 2 dan hasil nilai koefisien jalur pada Tabel 2 dan Tabel 3.

Pada Tabel 2 dapat diketahui bahwa pengaruh perceived risk terhadap trust memiliki hasil yang tidak signifikan dengan nilai koefisien jalur 0,097 dan nilai t-hitung 1,755 sehingga hipotesis kedua ditolak. Selanjutnya, pada hipotesis pertama sampai keempat kecuali hipotesis kedua, yaitu brand image, e-service quality, dan eWOM berpengaruh signifikan terhadap trust dengan nilai koefisien jalur di atas 0,05 dan nilai t-hitung di atas 1,96. Hipotesis kelima sampai kesembilan yaitu pengaruh brand image, perceived risk, eservice quality, eWOM, dan trust terhadap keputusan pembelian adalah signifikan, dengan nilai koefisien jalur di atas 0,05 dan nilai t-hitung di atas 1,96 .

Pada Tabel 3 dapat diketahui bahwa brand image dan eWOM berpengaruh signifikan terhadap keputusan pembelian melalui trust dengan nilai koefisien jalur di atas 0,05 dan nilai t-hitung di atas 1,96. Selanjutnya, dapat dilihat pula bahwa pengaruh perceived risk dan eservice quality terhadap keputusan pembelian melalui trust berpengaruh tidak signifikan dengan nilai koefisien jalur di bawah 0,05 dan nilai t-hitung di bawah 1,96.

\section{PEMBAHASAN}

Keputusan pembelian konsumen adalah membeli merek yang paling disukai dari berbagai alternatif yang ada (Kotler \& Amstrong, 2014). Pengambilan keputusan dari 
konsumen sejatinya adalah kumpulan dari beberapa keputusan yang teroganisir. Penting bagi konsumen untuk melakukan keputusan pembelian untuk pemenuhan kebutuhannya. Sebelum melakukan pembelian, proses keputusan pembelian konsumen sudah dimulai dan berlanjut setelahnya hingga pembelian ulang akan dilakukan konsumen.

Hasil penelitian menunjukkan brand image berpengaruh positif dan signifikan terhadap trust. Hal tersebut mengindikasikan positifnya tampilan sebuah brand image akan lebih banyak dilirik oleh konsumen. Konsumen sangat memberikan perhatian kepada brand image yang melekat pada produk. Jika kemudian produk dikonsumsi dan ternyata sesuai dengan ekspektasi, hal ini akan membuat kepercayaan terhadap merek tersebut meningkat. Makin bagus sebuah brand akan menghasilkan peningkatan trust konsumen. Hal tersebut didukung penelitian sebelumnya yang menyimpulkan bahwa brand image berpengaruh positif dan signifikan terhadap trust (Prasetya, Kumadji, \& Yulianto, 2014; Rodiques \& Rahanatha, 2018).

Riset ini menunjukkan perceived risk dengan trust berpengaruh positif dan tidak signifikan. Artinya, apabila perceived risk meningkat, maka cenderung tidak akan terjadi perubahan yang signifikan terhadap trust konsumen dalam melakukan pembelian melalui Instagram. Perceived risk tidak menjadi suatu hal yang perlu untuk dipertimbangkan dalam hal membangun kepercayaan konsumen. Banyak konsumen yang diduga tidak peduli dengan risiko yang dirasakan (Yuliati, Drajat, \& Simanjuntak, 2020). Responden dalam penelitian ini lebih fokus terhadap kelebihan yang ditawarkan dan diberikan saat melakukan pembelian secara online, seperti teknologi yang memudahkan segalanya, mudah melakukan pencarian barang yang diinginkan, mudah dalam pembayaran, dan lain-lain yang tidak bisa didapatkan jika dilakukan secara offline dibanding dengan risiko yang akan dirasakan. Hasil analisis didukung riset terdahulu yang mengungkapkan bahwa perceived risk memiliki berpengaruh yang tidak signifikan terhadap niat pembelian online (Zulfa \& Hidayat, 2018).

Hasil riset memperlihatkan e-service quality berpengaruh positif dan signifikan terhadap trust. E-service quality yang baik bisa dinilai dari kemudahan dihubungi suatu akun, dalam upaya untuk memenuhi kebutuhan pelanggan. Kualitas sebuah layanan berpengaruh terhadap trust pelanggan. Konsumen yang merasa nyaman dan terlayani dengan baik akan merasa puas, sehingga berimplikasi pada rasa percaya, karena pelayanan yang diterimanya sesuai dengan ekspetasi (Elrado, Kumadji, \& Yulianto, 2014). Hal ini sesuai dengan riset terdahulu yang menunjukkan bahwa kualitas pelayanan berpengaruh positif dan signifikan terhadap trust (Pramana \& Rastini, 2016).

Riset ini menemukan fakta bahwa eWOM berpengaruh positif dan signifikan terhadap trust. eWOM sangat menentukan kelayakan barang dari informasi yang dibagikan. Positifnya sebuah informasi yang tersebar dari konsumen terdahulu terhadap suatu produk akan meningkatkan trust kepada calon konsumen berikutnya. Konsumen akan menyampaikan pengalaman positif pembelian kepada temannya (Simanjuntak, 2020). Hasil analisis ini sesuai dengan riset terdahulu yang menyebutkan bahwa trust secara positif dan signifikan dipengaruhi oleh eWOM (Syafaruddin, Suharyono, \& Kumadji, 2016).

Hasil riset ini memperlihatkan pengaruh positif dan signifikan trust terhadap keputusan pembelian. Tinggi rendahnya trust konsumen akan sejalan dengan niat pembelian konsumen. Kemudian, trust dari seorang konsumen untuk bertransaksi online memengaruhi keputusan pembelian melalui internet. Hal ini berarti peningkatan trust konsumen dapat meningkatkan keputusan pembeliannya. Hal ini menunjukkan bahwa keputusan pembelian konsumen bisa didasari oleh rasa percaya konsumen terhadap produk sebuah perusahaan (Haekal, Suharyono, \& Yulianto). Hal ini didukung dengan penelitian terdahulu yang menyebutkan keputusan pembelian dipengaruhi secara signifikan dan positif oleh trust (Andini, Suharyono, \& Sunarto, 2014; Ashari \& Widayanto, 2018; Nawangsari \& Karmayanti, 2018).

Riset ini memperlihatkan bahwa brand image berpengaruh positif dan signifikan terhadap keputusan pembelian. Sebuah brand image mampu membuat persepsi di benak konsumen. Jika konsumen memiliki kesan yang positif terhadap merek, maka konsumen cenderung akan melakukan pembelian. Brand image yang terbentuk dengan baik akan memengaruhi keputusan pembelian konsumen karena mengetahui kualitas dari brand yang memproduksinya (Rachmawati \& Andjarwati, 2019). Hasil penemuan ini didukung penelitian terdahulu yang menyebutkan brand image sebuah online shop bisa memengaruhi 
keputusan pembelian di online shop (Heikal, 2017; Tanady \& Fuad, 2020).

Hasil penelitian memperlihatkan perceived risk berpengaruh negatif dan signifikan terhadap keputusan pembelian. Nilai koefisien jalur yang menunjukkan arah negatif memiliki arti bahwa apabila perceived risk yang diterima konsumen menurun atau berkurang, hal ini secara langsung akan meningkatkan keputusan pembelian konsumen. Dengan kata lain, produk yang memiliki risiko rendah lebih senang dipilih konsumen. Keputusan konsumen dan perilaku pembelian konsumen dapat dipengaruhi oleh risiko yang akan dihadapi konsumen (Chen \& Chang, 2012). Hasil ini didukung penelitian sebelumnya yang mengonfirmasi bahwa persepsi risiko akan memengaruhi keputusan konsumen (Yuliati, Simanjuntak, \& Oktriyanto, 2019).

Riset ini memperlihatkan pengaruh positif dan signifikan e-service quality terhadap keputusan pembelian. Konsumen dapat terpengaruh atas kualitas pelayanan dari perusahaan ketika akan melakukan keputusan. Pelayanan yang memuaskan akan membuat konsumen tanpa ragu membeli produk yang ditawarkan oleh pelaku usaha. Penting untuk bisa memperoleh konsumen baru dan meminimalisir kehilangan loyalitas konsumen dengan memberikan kualitas pelayanan yang prima. Hasil ini didukung penelitian sebelumnya yang mengungkapkan bahwa faktor kualitas pelayanan (quality of service) dan kenyamanan bisa memengaruhi keputusan pembelian konsumen secara signifikan (Pebriani, Sumarwan, \& Simanjuntak, 2018).

Hasil analisis SEM juga menunjukkan eWOM berpengaruh positif dan signifikan terhadap keputusan pembelian. Artinya, apabila eWOM sebuah akun online shop dari para pengguna Instagram baik, hal ini secara langsung akan meningkatkan keputusan pembelian konsumen. Saat ini konsumen sangat dipengaruhi oleh komentar positif dari konsumen lain dalam memutuskan pembelian. Dengan ikut sertanya konsumen lain dalam memberikan rekomendasi ataupun ulasan, contoh pada saat sharing review platform, hal ini dapat memengaruhi keputusan pembeliaan konsumen. Ulasan atau opini dari konsumen lain bisa memengaruhi sebuah keputusan pembelian. Hasil penelitian ini didukung penelitian terdahulu yang mengungkapkan bahwa terdapat pengaruh positif dan signifikan eWOM terhadap keputusan pembelian (Ramadhani \& Prihatini, 2019).
Penelitian membuktikan bahwa brand image berpengaruh positif dan signifikan terhadap keputusan pembelian melalui trust. Kesan terhadap merek yang positif akan membangun kepercayaan konsumen yang pada akhirnya akan mendorong konsumen untuk melakukan pembelian. Produsen dan konsumen samasama memandang merek sebagai sesuatu yang esensial. Konsumen akan mudah melakukan pembelian ketika sudah percaya terhadap merek. Hasil penelitian ini didukung penelitian terdahulu yang menunjukkan bahwa reputasi suatu brand image akan meningkatkan pengambilan keputusan konsumen dalam melakukan pembelian (Fikri et al., 2019).

Hasil analisis SEM menunjukkan pengaruh eWOM terhadap keputusan pembelian melalui trust adalah positif dan signifikan. eWOM positif merupakan salah satu faktor yang mempu meningkatkan trust calon konsumen karena mayoritas eWOM dibagikan konsumen terdahulu berdasarkan pengalamannya mengonsumsi produk pada masa lalu. Hasil analisis ini didukung penelitian terdahulu yang menemukan bahwa eWOM sangat berdampak pada trust dan juga pada keterlibatan proses keputusan pembelian (Prasad, Gupta, \& Totala, 2017).

Hasil analisis SEM juga menemukan bahwa pengaruh perceived risk dan e-service quality terhadap keputusan pembelian melalui trust adalah tidak signifikan. Hal ini membuktikan masih terdapat faktor lain yang dapat memediasi pengaruh perceived risk dan eservice quality terhadap keputusan pembelian, yang tidak dijabarkan pada penelitian ini. Persepsi konsumen terhadap risiko transaksi di Instagram tidak meningkatkan kepercayaan dan pada akhirnya tidak membuat konsumen melakukan pembelian. Dengan demikian, trust bukanlah variabel mediator atau intervening yang tepat antara variabel perceived risk dan keputusan pembelian serta antara e-service quality dan keputusan pembelian.

Berdasarkan hasil analisis SEM, brand image dan eWOM merupakan variabel yang paling dominan dalam memengaruhi keputusan pembelian konsumen. Para calon konsumen yang ingin melakukan pembelian di Instagram diharapkan selektif dalam memilih merek. Hal ini dikarenakan sebuah merek akan mampu menjamin kualitas dari produknya dengan mempertaruhkan reputasi perusahaannya, sehingga produk yang dibeli konsumen akan sesuai dengan harapan konsumen. Selanjutnya, konsumen bisa mencari lebih banyak informasi, khususnya dari sumber 
personal tepercaya, seperti teman, rekan kerja, dan saudara, atau bisa melakukan penelusuran di berbagai situs jejaring sosial dan mesin pencarian untuk mengumpulkan informasi terkait produk tersebut. Setiap akan melakukan transaksi, konsumen juga perlu menanyakan terkait garansi dan jaminannya. Pemerintah dan lembaga perlindungan konsumen harus lebih gencar dalam melakukan edukasi kepada konsumen dalam upaya meningkatkan keberdayaan konsumen. Hal ini mengingat makin maraknya transaksi yang dilakukan oleh konsumen secara online khususnya melalui Instgram. Konsumen harus didorong untuk melakukan pencarian informasi sebelum melakukan pembelian, melakukan perbandingan antar penjual dan antar merek, serta mempertimbangkan informasi yang diberikan oleh konsumen lain yang disuarakan secara eWOM.

\section{SIMPULAN DAN SARAN}

Hasil uji hipotesis menunjukkan bahwa terdapat pengaruh positif dan signifikan brand image dan eWOM terhadap keputusan pembelian melalui trust. Hasil uji hipotesis lainnya menunjukkan bahwa variabel perceived risk dan e-service qulity diketahui tidak berpengaruh signifikan terhadap keputusan pembelian melalui trust. Berdasarkan hasil analisis SEM, konsumen diharapkan bisa lebih selektif dalam memilih merek yang akan dibelinya dan mencari serta mengumpulkan informasi terkait barang yang akan dibeli. Edukasi kepada konsumen harus lebih gencar dilakukan oleh pemerintah dan lembaga perlindungan konsumen.

Keterbatasan penelitian ini yaitu hasil penelitian tidak bisa digeneralisasi untuk semua pengguna Instagram karena penentuan sampel dilakukan secara tidak acak. Keterbatasan lainnya adalah terdapat kemungkinan pelaku usaha di Instagram yang dinilai oleh konsumen juga melakukan penjualan di platform ecommerce sehingga penilaian tidak sematamata meliputi proses jual beli yang dilakukan di Instagram.

Berdasarkan hasil statistik deskriptif, penelitian selanjutnya diharapkan dapat mengkaji produk yang lebih spesifik seperti fashion, kuliner, kriya, elektronik, aksesoris, dan mainan dengan mengkombinasikannya pada e-commerce tertentu seperti Tokopedia, Bukalapak, dan Shopee. Variabel lain yang bisa diteliti, antara lain kepuasan konsumen dan loyalitas konsumen.

\section{DAFTAR PUSTAKA}

Andini, N. P., Suharyono, \& Sunarti. (2014). Pengaruh viral marketing terhadap kepercayaan pelanggan dan keputusan pembelian: Studi pada mahasiswa Fakultas IImu Administrasi Universitas Brawijaya angkatan 2013 yang melakukan pembelian online melalui media sosial Instagram. Jurnal Administrasi Bisnis, 11(1), 1-6. Retrieved from

http://administrasibisnis.studentjournal.ub .ac.id/index.php/jab/article/view/470.

Ashari, R., \& Widayanto. (2018). Pengaruh kepercayaan dan risiko terhadap keputusan pembelian melalui sikap pengguna pada situs belanja online lazada.com: Studi pada mahasiswa Fakultas IImu Sosial dan IImu Politik Universitas Diponegoro Semarang. Jurnal IImu Administrasi Bisnis, 7(1), 209-218. Retrieved from https://ejournal3.undip.ac.id/index.php/jia b/article/view/19162.

Chen, Y. S., \& Chang, C. H. (2012). Enhance green purchase intentions: the roles of green perceived value, green perceived risk, and green trust. Management Decision, 50(3), 502-520. doi: $10.1108 / 00251741211216250$.

Chong, W. K., \& Man, K. L. (2017). Examining e-marketing services and e-marketing performance with NK Model. In Proceedings of the International MultiConference of Engineers and Computer Scientists 2017 Vol II. Hong Kong. Retrieved from http://www.iaeng.org/publication/IMECS2 017/IMECS2017_pp695-696.pdf

Dailysocialid. (2016). Laporan customer satisfaction in Indonesia's e-commerce service tahun 2016. Retrieved from https://dailysocial.id/research/customersatisfaction-in-indonesias-e-commerceservices

Dewi, A. M. (2018). Pengaruh iklan online melalui instagram terhadap keputusan pembelian bagi peningkatan penjualan produk kuliner lokal. Ekonika, 3(1), 1-22. doi: 10.30737/ekonika.v3i1.78.

Elrado, H. M., Kumadji, S., \& Yulianto, E. (2014). Pengaruh kualitas pelayanan terhadap kepuasan, kepercayaan dan loyalitas (survei pada pelanggan yang menginap di jambuluwuk batu resort kota 
batu). Jurnal Administrasi Bisnis, 15(2), 1-9. Retrieved from http://administrasibisnis.studentjournal.ub .ac.id/index.php/jab/article/view/651.

Fikri, A., Nurmalina, R., Najib, M., Simanjuntak, M. (2019). The Effect of reputation on online repurchase intention of fruits/vegetables in indonesia with emotional and perceived risk as antecedent: based on the stimulusorganism-response model. Jurnal Manajemen \& Agribisnis, 16(2), 111-122. doi: 10.17358/jma.16.2.111.

Goyette, I., Ricard, L., Bergeron, J., \& Marticotte, F. (2010). eWOM: word of mouth measurement scale for e-service context. Canadian Journal of Administrative Sciences, 27(1), 5-23. doi: 10.1002/cjas.129.

Haekal, M. E., Suharyono, \& Yulianto, E. (2016). Pengaruh electoronic word of mouth terhadap kepercayaan dan keputusan pembelian: Survei pada konsumen produk fashion followers akun Instagram Erigostore. Jurnal Administrasi Bisnis, 40(2), 162-168. Retrieved from http://administrasibisnis.studentjournal.ub .ac.id/index.php/jab/article/view/1620.

Heikal, M. (2017). Pengaruh citra merek dan distribusi terhadap keputusan pembelian pada PT. Harian Waspada Medan. Jurnal Ekonomi Manajemen dan Bisnis, 18(1), 51-65. Retrieved from https://journal.unimal.ac.id/emabis/article/ view/284.

Hong, I. B. (2015). Understanding the consumer's online merchant selection process: The roles of product involvement, perceived risk, and trust expectation. International Journal of Information Management, 35(3), 322336. doi: 10.1016/j.ijinfomgt.2015.01.003.

Ibrahim, A. (2017, September 5). Kepuasan Konsumen Berbelanja Online Menurun. Mengapa?. TechnoBusiness. Retrieved from https://technobusiness.id/news/ecommerce/2017/09/05/kepuasankonsumen-berbelanja-online-menurunmengapa/.

Katadata. (2019). Tren Pengguna ECommerce Terus Tumbuh. Retrieved from

https://databoks.katadata.co.id/datapublis $\mathrm{h} / 2019 / 10 / 10 /$ tren-pengguna-ecommerce-2017-2023.
Kaur, G., \& Quareshi, T. K. (2015). Factors obstructing intentions to trust and purchase products online. Asia Pacific Journal of Marketing and Logistics, 27(5), 758-783. doi: 10.1108/APJML-10-20140146.

Keller, K. L. (2013). Strategic Brand Management (4th ed.). England, UK: Pearson Education.

Kotler, P., \& Amstrong, G. (2014). Principles of Marketing (15th ed.). New York, US: Pearson International.

Muhammad, R. N., Wibowo, L. A., \& Lisnawati. (2018). Gambaran kualitas informasi, shopping enjoyment dan keputusan pembelian pada followers Instagram Kamar Gadget. Journal of Business Management Education, 3(1), 97-106. doi: 10.17509/jbme.v3i1.14252.

Murwatiningsih, \& Apriliani, E. P. (2013). Pengaruh risiko dan harga terhadap keputusan pembelian melalui kepercayaan konsumen. Jurnal Dinamika Manajemen, 4(2), 184-191. Retrieved from

https://journal.unnes.ac.id/nju/index.php/j $\mathrm{dm} /$ article/view/2761.

Nawangsari, S., \& Karmayanti, Y. (2018). Pengaruh kepercayaan, kemudahan, dan kualitas informasi terhadap keputusan pembelian melalui media sosial instagram (Studi kasus pada online shop YLK.Store). In Konferensi Nasional Sistem Informasi 2018 (61-67). Pangkal Pinang. Retrieved from http://jurnal.atmaluhur.ac.id/index.php/kn si2018/article/view/336.

Paypal. (2018). Beyond Networking: Social Commerce as a Driver of Digital Payments. Retrieved from https://www.paypalobjects.com/digitalass ets/c/website/marketing/global/stories/im ages/paypal-asia-social-commercereport.pdf.

Pebriani, W. V., Sumarwan, U., \& Simanjuntak, M. (2018). The effect of lifestyle, perception, satisfaction, and preference on the online re-purchase intention. Independent Journal of Management \& Production, 9(2), 545561. doi: 10.14807/ijmp.v9i2.690.

Pramana, I. G. Y., \& Rastini, N. M. (2016). Pengaruh kualitas pelayanan terhadap kepercayaan nasabah dan loyalitas nasabah bank mandiri cabang veteran denpasar bali. E-Jurnal Manajemen, 5(1), 
706-733. Retrieved from https://ojs.unud.ac.id/index.php/Manajem en/article/view/18248.

Prasad, S., Gupta, I. C., \& Totala, N. K. (2017). Social media usage, electronic word of mouth and purchase-decision involvement. Asia-Pacific Journal of Business Administration, 9(2), 134-145. doi: 10.1108/APJBA-06-2016-0063.

Prasetya, C. H. A., Kumadji, S., \& Yulianto, E. (2014). Pengaruh citra merek, kualitas produk terhadap kepercayaan serta keputusan pembelian: Survei pada pembeli sepeda motor Honda Vario pada PT Sumber Purnama Sakti di Kabupaten Gresik. Jurnal Administrasi Bisnis, 15(2), 1-6. Retrieved from http://administrasibisnis.studentjournal.ub .ac.id/index.php/jab/article/view/644.

Priansa, D. J. (2016). Pengaruh ewom dan persepsi nilai terhadap keputusan konsumen untuk berbelanja online di Lazada. Jurnal Ecodemica, 4(1), 117124. doi: 10.31294/jeco.v4i1.353.

Rachmawati, E., \& Andjarwati, A. L. (2019). Pengaruh gaya hidup konsumtif dan promosi penjualan terhadap keputusan pembelian. Jurnal Ekonomi Akuntansi dan Manajemen, 18(2), 108-116. doi: 10.19184/jeam.v18i2.14712.

Ramadhani, R., \& Prihatini, A. E. (2019). Pengaruh electronic word of mouth dan perceived risk terhadap keputusan pembelian pada konsumen Tokopedia. Jurnal IImu Administrasi Bisnis, 8(1), 1-6. doi: 10.14710/jab.v8i1.23766.

Ramadhani, P. I. (2020, September 29). Bareskrim catat ada 1.617 kasus penipuan online pada 2019, paling banyak di Instagram. Liputan6. Retrieved from

https://www.liputan6.com/bisnis/read/436 9038/bareskrim-catat-ada-1617-kasuspenipuan-online-pada-2019-palingbanyak-di-instagram.

Restanti, F. A., Kusumawati, A., \& Devita, L. D. R. (2019). Pengaruh celebrity endorser dan electronic word of mouth terhadap minat beli dan dampaknya terhadap keputusan pembelian: Survei pada konsumen Zoya Fashion dan Hijab. Jurnal Administrasi Bisnis. 68(1), 28-37. Retrieved from http://administrasibisnis.studentjournal.ub .ac.id/index.php/jab/article/view/2796.
Rodiques, Y., \& Rahanatha, G. B. (2018). Peran brand trust memediasi hubungan brand image dengan brand loyalty:Studi pada konsumen iPhone di Kota Denpasar. E-Jurnal Manajemen, 7(3), 1310-1338. Retrieved from https://ojs.unud.ac.id/index.php/Manajem en/article/view/35936.

Rosalia, D., \& Ellyawati, J. (2016). Pengaruh persepsi risiko terhadap kepercayaan dan keputusan pembelian online. Jurnal Ekonomi Manajemen, 1(1), 1-9. Retrieved from http://ejournal.uajy.ac.id/8999/.

Rozi, I. F., \& Harti. (2017). Pengaruh e-service quality terhadap keputusan pembelian tiket kereta api online:Studi kasus konsumen pembeli tiket kereta api online PT. Kai Daop 8 Surabaya Gubeng. Jurnal Pendidikan Tata Niaga, 1(1), 118122. Retrieved from https://jurnalmahasiswa.unesa.ac.id/inde x.php/jptn/article/view/18432.

Shien, L. W., \& Yazdanifard, R. (2014). Relationship marketing vs. internet marketing; which one contribute to gain higher level of consumer loyalty. Global Journal of Management and Business Research: E Marketing, 14(7), 41-47. Retrieved from https://globaljournals.org/GJMBR_Volum e14/5-Relationship-Marketing-VsInternet-Marketing.pdf.

Simanjuntak, M. (2020). Consumer empowerment on online purchasing. Independent Journal Of Management \& Production, 11(1), 236-255. doi: 10.14807/ijmp.v11i1.964.

Simanjuntak, M., \& Hamimi, U. K. (2019). Penanganan komplain dan komunikasi Word-Of-Mouth (WOM). Jurnal IImu Keluarga \& Konsumen, 12(1), 75-86. doi: 10.24156/jikk.2019.12.1.75.

Sukma, A. A. (2012). Analisis faktor-faktor yang memengaruhi keputusan pembelian social networking websites. Jurnal Ekonomi Manajemen, 2(1), 1-21. Retrieved from https://docplayer.info/storage/52/3062876 7/30628767.pdf.

Syafaruddin, Z., Suharyono, \& Kumadji, S. (2016). Pengaruh komunikasi electronic word of mouth terhadap kepercayaan (trust) dan niat beli (purchase intention) serta dampaknya pada keputusan pembelian (survey pada konsumen 
online shopping zafertech.com). Jurnal Bisnis dan Manajemen, 3(1), 65-72. Retrieved from https://jurnal.unmer.ac.id/index.php/jbm/a rticle/view/75.

Tanady, E. S., \& Fuad, M. (2020). Analisis pengaruh citra merek dan kualitas layanan terhadap keputusan pembelian Tokopedia di Jakarta. Jurnal Manajemen, 9(2), 113-123. Retrieved from http://jurnal.kwikkiangie.ac.id/index.php/J $\mathrm{M} /$ article/view/663.

Tjakraatmadja, A. T. N., \& Harjanti, D. (2018). Pengaruh reputasi dan kepercayaan terhadap keputusan pembelian secara online pada produk kosmetik di instagram. AGORA, 7(1), 1-7. Retrieved from

http://publication.petra.ac.id/index.php/m anajemen-bisnis/article/view/7810.

Wardhana, N. K., Putra, I. W. J. A., \& Wahyudi, H. D. (2012). Pengaruh citra merek terhadap kepercayaan. Jurnal Ekonomi Bisnis, 17(1), 97-104. Retrieved from http://manajemen.fe.um.ac.id/wpcontent/uploads/2016/06/Handri-JEB2UM.pdf

We Are Social \& Hootsuite. (2020). Digital 2020: Indonesia. DataReportal. Retrieved from

https://datareportal.com/reports/digital2020-indonesia.

Widiyanti, W. (2017). Pengaruh persepsi kualitas produk, citra merek dan media iklan Instagram terhadap keputusan pembelian produk Ninebox: Studi kasus pada follower@ @tempattasdotcom. Cakrawala, 17(1), 40-50. doi: 10.31294/jc.v17i1.1885.

Yuliati, L. N., Dradjat, H. A., \& Simanjuntak, M. (2020). Online bike: Role of perceived technology, perceived risk, and institution-based trust on service usage via online trust. Cogent Business \& Management, 7(1), 1-19. doi: 10.1080/23311975.2020.1798067.

Yuliati, L. N., Simanjuntak, M., \& Oktriyanto, O. (2019). The Influence of information access, knowledge, perception of family planning's risks, and husband's support on interest of using contraception for unmet need group. Jurnal IImu Keluarga \& Konsumen, 12(2), 157-168. doi: 10.24156/jikk.2019.12.2.157.

Yutadi, K. P., \& Haris, L. (2014). Pengaruh persepsi privasi, persepsi keamanan, persepsi kepercayaan, persepsi risiko, persepsi kegunaan dan persepsi kemudahan penggunaan terhadap minat penggunaan e-commerce. Jurnal IImiah Mahasiswa Fakultas Ekonomi dan Bisnis, 3(1), 1-25. Retrieved from https://jimfeb.ub.ac.id/index.php/jimfeb/ar ticle/view/1487.

Zavareh, F. B., Ariff, M. S. M., Jusoh, A., Zakuan, N., Bahari, A. Z., \& Ashourian, M. (2012). E-service quality dimensions and their effects on e-customer satisfaction in internet banking services. Procedia - Social and Behavioral Sciences, 40, 441-445. doi: 10.1016/j.sbspro.2012.03.213.

Zulfa, L., \& Hidayat, R. (2018). Analisis pengaruh persepsi risiko, kualitas situs web, dan kepercayaan konsumen terhadap keputusan pembelian konsumen e-commerce shopee di Kota Semarang. Diponegoro Journal of Management, 7(3), 1-11. Retrieved from https://ejournal3.undip.ac.id/index.php/dj om/article/view/21024. 